\title{
UJI EFEK ANTIINFLAMASI EKSTRAK n-HEKSAN DAUN BERUWAS LAUT (Scaevola taccada (Gaertn.) Roxb) PADA MENCIT JANTAN (Mus musculus) YANG DIINDUKSI DENGAN KARAGEN
}

\author{
Sitti Amirah, Rahmawati, Safriani Rahman, Franita Achmad \\ Fakultas Farmasi Universitas Muslim Indonesia Makassar \\ Email : amirahsitti85@gmail.com
}

\begin{abstract}
This research about antiinflammation effect from n-hexane extract of Beruwas Laut leaves (Scaevola taccada (Gaertn.) Roxb.) in male mice (Mus musculus) was conducted, the aim was assay the antiinflammation effect of Beruwas Laut leaves done extract based on decrease in edema volume of foot palm male mice. This research using 15 male mice that evaluated and divided into 5 groups that each group has 3 mice. In group I, diclofenac sodium as the compare administrated. In groups II, III, dan IV, n-hexane Extract of Beruwas Laut leaves in concentration of $2,5 \%, 5 \%$ and $7,5 \%$ administrated. In group $\mathrm{V}, 1 \% \mathrm{Na}-\mathrm{CMC}$ as negative control administrated. Induction carried out by injection $1 \% \mathrm{w} / \mathrm{v}$ carrageen $0,1 \mathrm{ml}$ subcutan on the feet palm of mice. One hour later each group administered the preparation test $1 \mathrm{ml} / 30 \mathrm{gBW}$ orally. The measurement of edema volume carried out prior and after administration of the tested preparation 0, 30, 60, 90, and 120 minutes. The data correlation between induction and antiinflammation effect analysed. Result indicated variety with $n$-hexane extract of Beruwas Laut leaves have the antiinflammation effect at concentration $7,5 \%$.
\end{abstract}

Key Word : Antiinflammation, Scaevola taccada (Gaertn.) Roxb, Mice, n-Hexane.

\section{PENDAHULUAN}

Inflamasi atau radang merupakan suatu respons protektif normal terhadap luka jaringan yang disebabkan oleh trauma fisik, zat kimia yang merusak, atau zat - zat mikrobiologik (Mycek, 2001).

Obat antiinflamasi adalah suatu golongan obat yang memiliki khasiat analgesik (pereda nyeri), antipiretik (penurun panas), dan antiinflamasi (anti radang). Pada dasarnya obat ini relatif aman, apabila digunakan dalam dosis yang sesuai. Namun kekhawatiran justru timbul apabila obat-obat ini digunakan dalam dosis tinggi atau jangka panjang, sebab akan menimbulkan efek samping pada tubuh seperti keracunan hati, gangguan saluran pencernaan, gangguan ginjal, dan masih banyak lagi.

Oleh karena itu, diperlukan cara lain sebagai alternatif pengobatan 
Uji Efek Antiinflamasi Ekstrak N-Heksan Daun Beruwas Laut (Scaevola taccada (Gaertn.) Roxb) Pada Mencit Jantan (Mus musculus) Yang Diinduksi Dengan Karagen

yaitu dengan mencari sumber sumber obat baru, khususnya bahan obat tradisional yang dapat dikembangkan melalui penelitian dan pengembangan obat tradisional. Salah satu tumbuhan yang termasuk dalam bahan alam yang diduga memiliki efek antiinflamasi adalah beruwas laut (Scaevola taccada (Gaertn) Roxb).

Secara umum, beruwas laut digunakan sebagai obat tradisional untuk mengobati diabetes, sakit kepala, infeksi mata, bengkak pada kaki, pegal-pegal, batuk, flu, dan lain sebagainya. Adapun kandungan dari tumbuhan beruwas laut (Scaevola taccada (Gaertn.)Roxb.) adalah glikosid jenis skaevolin dan satu lagi jenis glikosid lain dari seluruh bagian tumbuhan ini, juga mengandung alkaloid, fenol, dan saponin (Ong, 2004 ; Soo, 2009).

\section{METODE PENELITIAN}

\section{Alat dan Bahan}

Alat - alat yang digunakan adalah pletismometer, rotavapor (Like Werke Ika RV05), timbangan analitik (Chiyco), timbangan kasar (O'hauss), dan timbangan hewan (Berkel).

Bahan - bahan yang digunakan adalah air suling, ekstrak daun beruwas laut (Scaevola taccada (Gaertn) Roxb.), etanol 96\%, nheksan, karagen, natrium diklofenak, natrium karboksimetil selulosa (Na$\mathrm{CMC}$ ), dan natrium klorida 0,9\%.

\section{Prosedur Kerja}

\section{Penyiapan Sampel dan Pengolahan}

Sampel yang digunakan dalam penelitian adalah daun beruwas laut (Scaevola taccada (Gaertn) Roxb.) yang berasal dari desa Suppa kabupaten Pinrang, Sulawesi Selatan.

Sampel yang telah
dikumpulkan, dicuci bersih terlebih dahulu setelah itu dilakukan perajangan atau dipotong - potong kecil. Selanjutnya, dikeringkan dengan cara diangin - anginkan tanpa paparan sinar matahari langsung.

\section{Pembuatan Bahan Penelitian}

Ekstraksi daun beruwas laut (Scaevola taccada (Gaertn.) Roxb.)

Sebanyak 200 gram sampel dimaserasi selama $5 \times 24$ jam dengan etanol 96\% $1000 \mathrm{ml}$, kemudian disaring dan ampasnya direndam kembali dengan cairan penyari yang baru. Hasil penyarian yang diperoleh dipekatkan dengan menggunakan rotavapor sampai diperoleh ekstrak etanol pekat.

\section{Pembuatan ekstrak n-heksan daun} beruwas laut (Scaevola taccada (Gaertn.) Roxb.)

Sebanyak 5 gram ekstrak etanol pekat dipartisi dengan pelarut $n$ - 
Uji Efek Antiinflamasi Ekstrak N-Heksan Daun Beruwas Laut (Scaevola taccada (Gaertn.) Roxb) Pada Mencit Jantan (Mus musculus) Yang Diinduksi Dengan Karagen

ekstrak n-heksan daun beruwas laut 2,5\%, kelompok III diberi ekstrak nheksan daun beruwas laut $5 \%$, kelompok IV diberi ekstrak n-heksan daun beruwas laut $7,5 \%$, dan kelompok V sebagai kontrol.

\section{Perlakuan terhadap Hewan Uji}

Mencit dipuasakan selama 8 jam sebelum perlakuan, kemudian ditimbang berat badannya. Semua hewan uji diukur volume kakinya menggunakan pletismometer, lalu disuntikkan karagen sebanyak 0,1 ml secara subkutan pada telapak kaki mencit. Hewan uji dipelihara selama 1 hari kemudian dilakukan kembali pengukuran volume kaki hewan uji yang telah diinduksi dengan karagen (volume awal). Hewan uji dibagi dalam 5 kelompok. Kelompok I diberi suspensi natrium diklofenak sebagai pembanding. Kelompok II diberi ekstrak $n$-heksan daun beruwas laut dengan konsentrasi 2,5\%. Kelompok III diberi ekstrak n-heksan daun beruwas laut dengan konsentrasi $5 \%$. Kelompok IV diberi ekstrak nheksan daun beruwas laut dengan konsentrasi $7,5 \%$. Kelompok $\mathrm{V}$ diberi suspensi Na-CMC sebagai kontrol. Seluruh pemberian pada mencit adalah peroral, selanjutnya dilakukan pengukuran dengan pletismometer.

\section{Penentuan volume edema}

Volume edema pada telapak kaki mencit (Mus musculus) diukur dengan cara mencelupkannya kedalam pletismometer setiap selang 30 menit selama 2 jam. Kemudian dilihat volume edemanya berdasarkan kenaikan raksa pada pletismometer.

\section{HASIL PENELITIAN}

Tabel 1. Data hasil pengukuran volume $(\mathrm{ml})$ inflamasi sebelum dan setelah waktu (menit) perlakuan

\begin{tabular}{c|c|c|c|c|c|c|c}
\hline \multirow{2}{*}{ Perlakuan } & \multirow{2}{*}{ Rep. } & Volume sebelum & Volume setelah & \multicolumn{3}{|c}{ Volume setelah perlakuan (mI) } \\
\cline { 5 - 8 } & & perlakuan $(\mathbf{m l})$ & induksi $(\mathbf{m l})$ & $\mathbf{3 0 "}$ & $\mathbf{6 0}$ & $\mathbf{9 0 "}$ & $\mathbf{1 2 0}$ \\
\hline Kelompok I & I & 0,133 & 0,664 & 0,664 & 0,398 & 0,266 & 0,266 \\
Na- & II & 0,133 & 0,664 & 0,531 & 0,531 & 0,266 & 0,266 \\
diklofenak & III & 0,133 & 0,664 & 0,531 & 0,398 & 0,266 & 0,133 \\
\hline \multirow{2}{*}{ Kelompok II } & I & 0,133 & 0,398 & 0,531 & 0,531 & 0,531 & 0,398 \\
Ekstrak 2,5\% & II & 0,133 & 0,398 & 0,398 & 0,398 & 0,398 & 0,398 \\
& III & 0,133 & 0,398 & 0,398 & 0,398 & 0,398 & 0,398 \\
\hline \multirow{2}{*}{ Kelompok III } & I & 0,133 & 0,531 & 0,398 & 0,398 & 0,398 & 0,398 \\
Ekstrak 5\% & II & 0,133 & 0,398 & 0,531 & 0,398 & 0,266 & 0,266 \\
& III & 0,133 & 0,398 & 0,266 & 0,266 & 0,266 & 0,266 \\
\hline \multirow{2}{*}{ Kelompok IV } & I & 0,133 & 0,531 & 0,531 & 0,398 & 0,398 & 0,266 \\
Ekstrak 7,5\% & II & 0,133 & 0,531 & 0,398 & 0,398 & 0,398 & 0,266 \\
& III & 0,133 & 0,531 & 0,398 & 0,398 & 0,398 & 0,398 \\
\hline
\end{tabular}


Uji Efek Antiinflamasi Ekstrak N-Heksan Daun Beruwas Laut (Scaevola taccada (Gaertn.) Roxb) Pada Mencit Jantan (Mus musculus) Yang Diinduksi Dengan Karagen

\begin{tabular}{c|c|c|c|c|c|c|c}
\hline Kelompok V & I & 0,133 & 0,531 & 0,531 & 0,531 & 0,531 & 0,531 \\
Na-CMC 1\% & II & 0,266 & 0,531 & 0,398 & 0,398 & 0,398 & 0,398 \\
& III & 0,266 & 0,531 & 0,398 & 0,398 & 0,398 & 0,398 \\
\hline
\end{tabular}

\section{PEMBAHASAN}

Inflamasi atau radang merupakan suatu respons protektif normal terhadap luka jaringan yang disebabkan oleh trauma fisik, zat kimia yang merusak, atau zat - zat mikrobiologik. Inflamasi adalah usaha tubuh untuk menginaktivasi atau merusak organisme yang menyerang, menghilangkan zat iritan, dan mengatur derajat perbaikan jaringan.

Metode pengujian antiinflamasi yang digunakan pada penelitian ini adalah penurunan volume edema kaki mencit jantan yang diinduksi dengan karagen $1 \%$ secara subkutan. Penggunaan karagen sebagai penginduksi edema karena karagen bersifat netral yang hanya menyebabkan edema dan tidak menyebabkan nekrosis (kematian jaringan). Selain itu karagen mudah diterima oleh fisiologis tubuh sehingga respon inflamasi cepat terjadi dan pembengkakannya lebih nyata sehingga mudah untuk diamati.

Penelitian ini menggunakan hewan coba mencit karena susunan gen pada mencit hampir sama dengan manusia. Selain itu mencit lebih mudah penanganannya dibandingkan hewan coba lain. Digunakan mencit jantan karena proses absorpsi obat pada mencit jantan tidak dipengaruhi oleh sistem hormonalnya, berbeda dengan mencit betina karena sistem hormonal pada mencit betina dapat berpengaruh pada saat pemberian obat karena dapat mengalami siklus estrus.

Penurunan volume edema kaki mencit jantan (Mus musculus) diukur dengan menggunakan pletismometer dengan prinsip pengukuran berdasarkan hukum Archimedes yaitu benda yang dimasukkan kedalam zat cair akan memberi gaya atau tekanan keatas sebesar volume yang dipindahkan. Metode ini lebih sederhana, cepat, dan hasil pengukuran yang didapatkan lebih akurat dibandingkan dengan alat yang lain.

Pembanding yang digunakan yaitu natrium diklofenak. Natrium diklofenak merupakan golongan AINS yang mekanisme kerjanya dapat menghambat pembentukan siklooksigenase-2 (COX-2) yang merupakan enzim pemicu terbentuknya prostaglandin (mediator peradangan) di dalam jaringan, jumlah 
Uji Efek Antiinflamasi Ekstrak N-Heksan Daun Beruwas Laut (Scaevola taccada (Gaertn.) Roxb) Pada Mencit Jantan (Mus musculus) Yang Diinduksi Dengan Karagen

enzim ini akan meningkat jika terjadi peradangan. Obat ini berefek kuat sebagai antiradang serta diserap secara cepat dan lengkap melalui saluran cerna.

\section{Kelompok}

$\mathrm{Na}-\mathrm{CMC}$ menunjukkan nilai yang signifikan terhadap Natrium Diklofenak dan ekstrak n-heksan daun Beruwas Laut (Scaevola taccada (Gaertn.)Roxb.) konsentrasi $5 \%$ dan $7,5 \%$ dengan nilai berturut-turut adalah $0,000,0,021$, 0,001, dan tidak signifikan terhadap ekstrak konsentrasi 2,5\%. Hal ini berarti, Na-CMC memiliki efek yang berbeda dengan efek Natrium Diklofenak dan ekstrak n-heksan konsentrasi $5 \%$ dan 7,5\%, dan memiliki efek yang sama dengan ekstrak n-heksan konsentrasi 2,5\%.

Kelompok Natrium Diklofenak menunjukkan nilai yang signifikan terhadap ekstrak n-heksan daun Beruwas Laut (Scaevola taccada (Gaertn.) Roxb.) konsentrasi 2,5\%, 5\% dan $7,5 \%$, dengan nilai yaitu 0,000 , $0,000,0,000,0,001$. Hal ini berarti, efek penurunan inflamasi Natrium Diklofenak berbeda dengan efek ekstrak n-heksan konsentrasi 2,5\%, $5 \%$, dan $7,5 \%$.

Kelompok ekstrak n-heksan daun Beruwas Laut (Scaevola taccada (Gaertn.) Roxb.) konsentrasi 2,5\% menunjukkan nilai yang signifikan terhadap ekstrak n-heksan konsentrasi $7,5 \%$ dengan nilai yaitu 0,021 , dan tidak signifikan terhadap ekstrak nheksan konsentrasi 5\%. Hal ini berarti, efek penurunan inflamasi ekstrak nheksan daun Beruwas Laut konsentrasi 2,5\% berbeda dengan ekstrak n-heksan konsentrasi 7,5\% dan memiliki efek yang sama dengan ekstrak n-heksan konsentrasi 5\%.

Kelompok ekstrak n-heksan daun Beruwas Laut (Scaevola taccada (Gaertn.) Roxb.) konsentrasi 5\% menunjukkan nilai yang tidak signifikan terhadap ekstrak n-heksan daun Beruwas Laut konsentrasi 7,5\% dengan nilai yaitu 0,097. Hal ini berarti, efek penurunan inflamasi ekstrak nheksan daun Beruwas Laut konsentrasi 5\% sama dengan efek ekstrak n-heksan daun Beruwas Laut konsentrasi $7,5 \%$.

Hasil analisis menunjukkan bahwa ekstrak n-heksan daun Beruwas Laut (Scaevola taccada (Gaertn.) Roxb.) konsentrasi 2,5\% dan $5 \%$ tidak berpotensi sebagai antinflamasi karena memiliki efek yang sama dengan $\mathrm{Na}-\mathrm{CMC}$, dan ekstrak nheksan daun beruwas laut konsentrasi $7,5 \%$ mempunyai potensi sebagai antiinflamasi meskipun efeknya lemah. 
Uji Efek Antiinflamasi Ekstrak N-Heksan Daun Beruwas Laut (Scaevola taccada (Gaertn.) Roxb) Pada Mencit Jantan (Mus musculus) Yang Diinduksi Dengan Karagen

\section{KESIMPULAN}

Hasil penelitian yang telah dianalisis menyimpulkan bahwa :

1. Ekstrak n-heksan daun Beruwas Laut (Scaevola taccada (Gaertn.) Roxb.) mempunyai efek sebagai antiinflamasi terhadap mencit jantan (Mus musculus).

2. Ekstrak n-heksan daun Beruwas Laut (Scaevola taccada (Gaertn.) Roxb.) konsentrasi $7,5 \%$ dapat memberikan efek antiinflamasi pada mencit jantan (Mus musculus).

\section{DAFTAR PUSTAKA}

Dirjen POM. 1979.Farmakope Indonesia.(Edisi 3). Jakarta: Departemen Kesehatan Republik Indonesia.

Dirjen POM. 1986.Sediaan Galenik. Jakarta: Departemen Kesehatan Republik Indonesia.

Ganiswarna, S. G. 2000.Farmakologi dan Terapi. (Edisi 5). Jakarta: Bagian Farmakologi FK UI.

Gennaro, A.R. 1990. Remington's Pharmaceutical

Science.(18th ed).

Pennsylvania: Mack

Publishing Company.

Guyton. 1996. Fisiologi

Kedokteran.(Edisi 9). Jakarta:

Penerbit Buku Kedokteran

EGC.

Harborne, J.B. 1987. Metode Fitokimia : Penuntun Cara Modern Mengekstraksi Tumbuhan. Penerjemah:
Padmawinata.Bandung: Penerbit ITB.

Hean C.O. 2004.Tumbuhan liar: khasiat ubatan \& kegunaan. Diakses 8 Oktober 2011.http://www.scribd.com/d oc/64909444/Bio-Divers-ItAs.

Herlina, W. 2002.Alkitab Tanaman Obat Nusantara disertai Pengobatan. Yogyakarta: Media Presindo.

Heyne, K.1987.Tumbuhan Berguna Indonesia (Edisi 3). Jakarta: Badan Litbang Kehutanan.

Jassin \& Soemkari. 1992.Zoologi Vertebrata untuk Perguruan Tinggi. Surabaya: PT. Antariksa.

Katzung, B.G. 2002.Farmakologi Dasar dan Klinik. Jakarta: Salemba Medika.

Kibbe, A.H. 2000. Handbook of Pharmaceutical

Excipient.(3rd ed). London: American Pharmaceutical Association.

Kee, J.L. \& Hayes, E.R. 1996. Farmakologi Pendekatan Proses Keperawatan.Jakarta: Penerbit Buku Kedokteran EGC.

LIPI.

$$
2011 .
$$
Hasil Identifikasi/Determinasi Tumbuhan Beruwas Laut. Bogor: Pusat Penelitian Biologi.

Malole, M.B.M. \& Pramono, C.S.I. 1989.Penggunaan HewanHewan Percobaan di 
Uji Efek Antiinflamasi Ekstrak N-Heksan Daun Beruwas Laut (Scaevola taccada (Gaertn.) $\underline{\text { Roxb) }}$ Pada Mencit Jantan (Mus musculus) Yang Diinduksi Dengan Karagen

Laboratorium. Jakarta:

Departemen Pendidikan dan Kebudayaan.

Mycek, M.J., Harvey, R.A., \& Champe P.C.2001. Farmakologi Ulasan Bergambar.(Edisi II). Jakarta: Widya Medika.

Price, S.A. \& Wilson, L.M.1995. Patofisiologi Konsep Klinis Proses - Proses Penyakit. Jakarta: Penerbit Buku Kedokteran EGC.

Tobo, F. 2001.Buku Pengantar Laboratorium Fitokimia $I$. Makassar: Laboratorium Fitokimia Jurusan Farmasi Fakultas MIPA Universitas Hasanuddin.

Wardini, T.H.2011.Medicinal and poisonous plants. Diakses 7 Oktober 2011.http://www.proseanet.or $\mathrm{g} /$ florakita/browser.php?docsi $\underline{d=747}$.

Soo, S.Y.2009.Medical Plants in Papua New Guinea. Western Pacific: WHO Press.

Tan, H. T. \& Raharja, K.2002. Obat Obat Penting.(Edisi 5). Jakarta: PT.Elexmedia Computindo Kelompok Gramedia.

Widodo, S. 2001.Farmakoterapi dalam Neurologi. Jakarta: Salemba Medika.

Yamato, M. 2011. Scaevola taccada. Diakses 8 Oktober 2011.http://muherda.blogspot .com/2011/02/scaevolataccada.html 